\title{
ECONOMIC ASPECTS OF PENSION PLANS
}

\author{
JohN O. BLACKBURN*
}

The rapid growth of pension plans and funds in recent decades, whether measured by participants, number of plans, volume of assets, or such other yardsticks as may be devised, has attracted widespread attention in business, government, and academic circles. It is the purpose of this paper to review some recent developments with respect to pension and retirement plans, to examine some of the reasons for these developments, and to assess their significance for the American economy.

\section{Factors Influencing Pension Plans}

A number of influences-sociological, economic, and legal-have coincided to produce the near-explosive growth which has characterized pension funds in the past few decades. One such factor is the changing age structure of the population, a phenomenon discussed elsewhere in this symposium. ${ }^{1}$ Urbanization, industrialization, and a host of other factors have changed the pattern of living of the aged, so that separate residence with little or no financial dependence on children is increasingly looked upon as the norm, if not always realized in practice.

It is by no means a novel problem that the aged must be somehow supported, more than likely in amounts above and beyond their own current contributions to production. The novel elements are that there are so very many more of the aged than in previous generations, and that their consumption is coming to be financed in increasing degree through saving plans involving a large element of compulsion. For consumption spending by the aged in excess of their current labor incomes must be financed either by gifts-family, private institutions, or government-or by accumulated savings. Some people do save for their retirement, and undoubtedly have done so for centuries. However, the number of those who save in sufficient amounts to support a level of expenditure acceptable to the conscience of an increasingly affluent society appears to be relatively small. For the most part, people seem to be unable or unwilling to formulate and execute individual financial plans to provide sufficiently for their old age.

The establishment of formal financial machinery to accumulate funds for retirement on a more or less compulsory basis is a phenomenon which may be observed at a variety of levels in the United States economy. The most widespread arrangement is, of course, the Old Age, Survivors, and Disability program operated by the federal government. Established by the Social Security Act of 1935, the program

- A.B. 1951, Duke University; Ph.D. I959, University of Florida. Assistant Professor of Economies, Duke University. Certified Public Accountant, Florida. Contributor to economic periodicals.

${ }^{2}$ See Spengler, Aging Populations: Mechanics, Fistorical Emergence, Impact, at pp. 2-21 supra. 
has been broadened by subsequent amendments so that an estimated ninety-two to ninety-seven per cent of all males and sixty to seventy per cent of all females in the population will eventually be retired with full insurance. ${ }^{2}$ Likewise maintained by the federal government are pension funds for railroad workers and for its own civil service employees. Employees of state and local governments are in most cases covered by pension plans of one variety or another, the earliest such plan being that of New York City, established in 1878 .

Perhaps the most striking feature of the entire pension structure is the largescale development of non-governmental plans by private employers. From extremely modest beginnings about the turn of the century, private employee pension plans mushroomed by $x 960$ to an estimated $\$ 50$ billion in assets. ${ }^{3}$ Private plans in I959, the latest year for which such information is now available, covered 20 million employees, or twenty-nine per cent of the non-governmental labor force. ${ }^{4}$ One might well raise the question as to the reason for such growth in private plans at a time when the federal system was becoming well-established, with continually broadening coverage and liberalization of benefits. It is difficult to give a definitive answer to this question; however, among the factors frequently mentioned by writers in the field are tax legislation, wartime conditions, and collective bargaining.

Tight labor markets during World War II and the Korean conflict, together with frozen wage rates, led employers to seek means of raising wages without actually raising stated hourly rates of compensation. Increased fringe benefits, including pensions, were a natural result. The existence of excess-profit taxation made such payments virtually costless to the employer, at least in the short run, thus providing an additional stimulus. Of equal or greater importance has been union pressure in collective bargaining, reflecting a greatly increased interest in pensions by union leadership. The legal foundation for this development is a I948 decision of the National Labor Relations Board in which it was held that pension plans are a bargainable issue. 5 Among other possible influences are the role of the federal program in making the public conscious of old-age security needs, the desire of employers to reduce labor turnover and improve morale-hence, possibly productivity-or perhaps a growing sense of social responsibility in the corporate business community.

\footnotetext{
${ }^{2}$ Board of Trustees of the Federal Old Age and Survivors Insurance Trust Fund and the Federal Disability Trust Fund 2ist Ann. Rep. 38 (I96I).

${ }^{8}$ Securities and Exchange Comm'n, Corporate Pension Funds r960, Release No. 1750, Dec. 31, 196r.

'Skolnik, Trends in Employee Benefit Plans: Part 2, Soc. Sec. Bull., May I961, p. 6. Not included in the figure given are 1.6 million beneficiaries already retired, or in some cases beneficiaries other than covered employees.

${ }^{8}$ Inland Steel Co. v. United Steelworkers of America (C.I.O.), 77 N.L.R.B. 4 (1948), enforcement granted, Inland Steel Co. v. N.L.R.B., r7o F.2d 247, 25I (7th Cir. I948), cert. denied, 336 U.S. 960 (1949).
} 


\section{The Economic Impact of Pension Funds}

Whatever the reasons involved, pension plans now have a profound impact on our economy and society, and this influence is likely to be even greater in the future. The volume of saving from given levels of national income, the pattern of consumption spending, the size of the national wealth, its forms and means of ownership, the levels of interest rates and stock yields-all such economic quantities will be increasingly influenced by the operation of pension funds. The level of pension saving carries implications for the rate of capital formation and economic growth as well as for levels of production and employment.

\section{A. Pension Funds and Aggregate Saving}

Pension fund accumulations represent saving from the standpoints of both the individuals concerned and the national income and product accounts, in as much as saving is defined as income not currently expended on consumption items. Employer contributions to funds are, to be sure, not taxable income to the individuals on whose behalf they are made, and the legal status of such payments is ambiguous. Nevertheless, contributions represent additional labor costs to the employer, and can most conveniently be accommodated in economic theory as wages or salaries constructively received and saved via the pension funds. This treatment is used in the preparation of the United States national income estimates. Clearly, then, the volume of saving through pension plans can affect the economy's aggregate saving, unless any increase in pension fund saving is exactly offset by a decrease in other forms of saving by individuals. For several reasons, it is very likely that the growing practice of saving through pension funds will increase the volume of national saving.

First, while it is true that employers covered by plans are accumulating assets in the form of claims for future benefits, these assets are likely to be highly illiquid. Indeed, they may be collectible only under rather rigid conditions of age and service. Thus, they cannot readily be substituted for other forms in which individual savings are held, such as savings deposits, securities, real estate, and the like. In order for pension savings increases to be exactly offset by decreases in other private savings, individual assets in the form of present values of future benefit payments would have to be highly substitutable for other customarily held assets.

Secondly, formal pension plans may even increase other forms of saving by introducing the idea of systematic provision for the future to millions of individuals who customarily save little, if any. It is a statistical fact in the United States that the bulk of the nation's saving is done by high-income groups, with savings zero or negative, on the average, among low-income groups. There is no doubt that the coverage of present plans reaches well into the latter income bracket, where it may have the possible result of increasing non-pension. saving as well. 
Thirdly, there are some formidable tax advantages to saving through pension funds. Employer contributions, which may be viewed as additional income to employees, are excluded from taxable income and taxed, if at all, only when the employee is retired (and presumably in a lower tax bracket). Likewise exempt is property income earned by pension funds. The tax provisions, then, amount to an additional exemption for any income saved in this particular form, an inducement not only to save through pension funds but to save more out of a given income than would otherwise be the case. ${ }^{8}$

The level of national saving is, of course, directly relevant to such matters as the rates of capital formation and economic growth, the level of interest rates, and the maintenance of sufficient aggregate demand to insure full employment. If, as may well be possible, the volume of saving through pension plans tends to increase the rate of overall national saving, then we shall have the means to finance an accelerated flow of investment in productive facilities, a basic consideration in the much-publicized controversy over economic growth rates. If, on the other hand, our economy has developed a chronic tendency to oversave with respect to profitable investment opportunities, developments in pension planning are likely to aggravate this difficult situation. Opposing viewpoints as to the future course of saving-investment relationships are held by competent economists; any attempt to argue the matter is beyond the scope of this paper. Nevertheless, it is appropriate to stress the important role played by pension funds in aggregate saving.

\section{B. Pension Funds and the Capital Markets}

The nation's capital markets represent another point of impact of pension savings. Decisions on the part of those responsible for managing accumulated funds are of primary importance in the securities markets. Non-insured pension trusts are now the largest net annual purchasers of corporate stocks. They held, at the end of $1960, \$ 14.6$ billion (at market value) ${ }^{7}$ of an estimated total of $\$ 442$ billion outstanding. ${ }^{8}$ Even these figures understate the importance of fund operations for particular issues. Pension funds, in so far as they hold common stocks (forty-five per cent of 1960 assets), confine their attention almost completely to listed securities, and of these there is some evidence that "blue chips" get the lion's share.

Wealth, as a few moments' reflection will make clear, exists basically in the form of land, structures, machinery, equipment, and inventories of goods-tangible assets, in short. Such assets as money or securities, which readily come to mind

- See generally, Strecker, Taxation of Retirement Provision, at pp. 67-88 supra.

7Securities and Exchange Comm'n, supra note 3. Privately administered (i.e., nongovernmental) pensions are typically placed with insurance companies (\$I9 billion in 1960) or handled by trust arrangements ( $\$ 28.7$ billion in 1960$)$. In so far as funds are administered by insurance companies, portfolio decisions are made in the broader context of managing the entire asset portfolio. Life insurance companies, by far the largest of the financial intermediaries, held, at the end of 1959, assets of $\$ 113.7$ billion. Institute of IIFe Insurance, I960 Life INSURANCE Fact Book 62 (1960).

${ }_{47}$ Fed. Reserve Bull. 485 (196I). 
at the mention of the term "wealth," are in reality only claims against tangible or "real" wealth, or claims against income derived from the use of real wealth. Bank deposits (money), for example, are claims against (liabilities of) commercial banks "backed up" by bank assets. Bank assets, however, consist largely of claims against the business community which in turn holds the bulk of the nation's real wealth. The same line of reasoning may be applied to corporate stocks or bonds or indeed to any of the wide variety of intangible assets.

It is one of the marks of economic development and sophistication that there exists such a wide variety of claims against wealth in an economy, many of them of a highly liquid nature. An individual in the United States may hold his wealth in the form of currency, bank deposits, savings and loan shares, government securities, corporate bonds, corporate stocks, insurance cash surrender values, and other intangibles of lesser importance, as well as in real estate and other tangible forms.

Pension fund managers, like other managers of wealth, are confronted with the same bewildering variety of investment (wealth-holding) possibilities as anyone else. Presumably, they make their decisions on the basis of security, liquidity, maturity, yield (and, lately, purchasing-power protection), as do other investors. It is a fact of great importance, however, that large groups of assets available to individuals are, by their nature, ruled out of consideration as investment outlets for pension funds. The result is that investments of non-insured (trustee-managed) funds are almost wholly concentrated in common stocks, corporate bonds, and government securities (ninety-two per cent in 1960 )..$^{9}$ As to insured plans, it is not possible to separate assets held against pension liabilities from asset totals. Nevertheless, the three categories accounted, in 1959, for fifty-four per cent of total insurance company assets. ${ }^{10}$ The only other major outlet for insurance company funds is mortgages, (thirty-four per cent of assets in 1959) which suggests that trusteed funds might also look in this direction. ${ }^{11}$ Real estate provides another potential outlet, indeed virtually the one remaining, though it is as yet barely exploited. Real estate accounted for three per cent ${ }^{12}$ of all insurance assets in I959, but was not of sufficient importance to be mentioned as a category of non-insured fund assets.

As has already been suggested, the concentration of fund operations becomes more striking in view of the fact that not all of the assets in each of the above categories are suitable for investment by pension funds. Whereas pension funds held, at the end of I960, stocks valued at \$14.6 billion, or 3.3 per cent of outstanding corporate stocks, the percentage increases if only the more popular issues (which make up the bulk of fund holdings) are considered. Of greater significance for the future, perhaps, is the fact that in 1960 , net purchases of stocks by pension funds

\footnotetext{
- Securities and Exchange Comm'n, supra note 3.

${ }^{20}$ InstituTE of LIFE INSURsNce, op. cit. supra note 7, at 65.

12 lbid.

${ }^{2}$ Ibid.
} 
were $\$ \mathrm{I} .8$ billion, whereas total net additions to outstanding stocks amounted to $\$ 3.4$ billion. While the two figures are not strictly comparable, it is clear that pension funds had become by Ig6o by far the largest net purchasers of stocks, absorbing stocks approximately equal in value to one half of net new issues. ${ }^{13}$

\section{III}

\section{Social and Legal Implications of Pension Fund Growth}

These developments in the financing of retirement are not without social and legal consequences. What is the nature, for example, of the rights of an individual covered under a pension plan, when the governing contract is between his employer and the pension fund trustee, or perhaps between the employer and the union, in a collectively bargained pension agreement? Or, to consider a related question, who "owns" the assets of pension funds? Employers generally do not, for pension plans, in order for contributions to be deductible in computing taxable net income, must be for the exclusive benefit of employees or their beneficiaries, with safeguards against diversion to other uses. Trustees, by the nature of their responsibilities, do not "own" the assets. Curiously enough, the beneficiaries have few, if any, of the characteristics of ownership. Thus, there exists a large and rapidly-growing body of wealth which is "owned" by no one in particular, at least in terms of any conventional notions of ownership or property rights.

Still another related matter is the exercise of control over property, as distinct from the question of ownership. The evolution of the modern corporation, with the accompanying divorce of ownership and effective control, is by now a familiar theme. The related (and somewhat delayed) evolution in legal, political, and economic thought, if not complete, is at least well under way. We have more or less come to terms with the changed concepts of "property," "rights," and "ownership" implicit in the existence of giant corporations. The growth of pension funds and similar institutional investors, however, suggests that these same concepts are in for another overhauling.

It is true, of course, that financial intermediaries such as banks and insurance companies have for a long time held securities of, and other claims against, the business community (including corporations). However, these claims have traditionally been in the nature of debt, not equity claims, and they have been accommodated with little difficulty into the existing legal and economic concepts of debtor-creditor relationships. The growing practice by pension funds of investing in common stocks, however, raises new questions. Much has been made of the concentration of corporate assets, production, and employment in the hands of some arbitrarily selected number of the largest corporations. Suppose now that substantial blocks of stock in these corporations come into the hands of pension trustees. Pension trustees are, more often than not, banks, with the nation's largest banks

\footnotetext{
${ }^{13}$ Securities and Exchange Comm'n, supra note 3.
} 
(mostly in New York) holding the vast majority of trusteed assets. ${ }^{14}$ Although there is no reason to believe that they now exercise such control, it is possible that a relatively few bank trust departments, by virtue of their status as pension trustees (as well as trustees for individuals, in which capacity banks, mostly large banks, hold an unknown but apparently large volume of assets) could vote blocks of stock sufficiently large to influence or control the managers of the bulk of all corporate assets.

These questions are treated well and at length in a recent study by Paul P. Harbrecht, supported by the Twentieth Century Fund. ${ }^{15}$ Professor Harbrecht, in view of the circumstances only briefly outlined above, argues that present notions of property rights and ownership are in need of revision-indeed, that the whole structure of relationships between men and things is changing. He, like other writers confronted with new situations, invents a new word; he suggests that our society be called a "paraproprietal society."

While a full discussion of these matters is beyond the scope of this paper, it is questionable whether things have changed as radically as Professor Harbrecht so persuasively argues. The separation of ownership and control with respect to publiclyheld corporations has been so nearly complete for several decades that the interposition of another layer of intermediaries between 'corporations and ultimate receivers of dividend checks would appear to make little difference. Indeed, the concentration of a sizable minority holding of shares in the hands of anyone, even trustees, might make management more responsive to stockholders as a class. The latter are now, by common consent, largely ignored between the annual ritual performances that stockholders' meetings have become. Still, regardless of viewpoints on this particular question, there are clearly some live issues with respect to pension funds and concepts of property rights.

\section{IV}

\section{Recent Developments and Future Prospects}

The remainder of this paper is devoted to a resumé of recent trends in pension fund finances, and to a consideration of their future prospects. After a summary of the more important developments in the postwar period, some questions will be raised as to the relationship between pension funds and the economic variables already discussed. As an approach to answering these questions, there will be developed a simplified economic model which will be used to illustrate the role of the relevant variables in analyzing pension funds. Finally, some conclusions with respect to the United States economy will be drawn.

${ }^{14}$ A study of 1,024 (all bank trusteed) plans by the New York State Banking Department found that 98:5\% of plan assets in I 953 were administered by the nation's I3 largest banks. GeOrGE A. MooNEY, Pension and Other Employee Welfare Plans (N. Y. State Banking Dep'r), reprinted in Paul P. Harbrecht, S. J., Pension Funds and Economic Power 225 (1959).

${ }^{15}$ HARBRECHT, op. cit. sitpra note 14 . 


\section{A. Recent Developments}

Assets of corporate noninsured pension funds reached a level of $\$ 28.7$ billion at book value, or $\$ 32.2$ billion at market value by the end of $1960 .{ }^{10}$ When these amounts are added to insured pension reserves of $\$ \mathrm{x} 9.0$ billion, other private funds ${ }^{17}$ of $\$ 2.3$ billion, and public funds of $\$ 55.9$ billion, the total of all pension funds on December 3r, I960 reached an estimated \$105.9 billion. Excluding the social security funds of $\$ 22.6$ billion (which are virtually on a pay-as-you-go basis with no attempt to fund future liabilities beyond existing reserves) the total of funds administered more or less on an actuarial basis amounted to $\$ 83.3$ billion. ${ }^{18}$

A few comparisons may help to place this enormous figure in perspective. The total for $195^{\circ}$ was $\$ 23.8$ billion, giving the pension funds a compounded growth rate of approximately thirteen per cent for the ten-year period. The entire national wealth was estimated at roughly $\$ 1,050$ billion in $1950 .{ }^{10}$ The 1960 figure is not available, but may have been in the neighborhood of $\$ 1,890$ billion, extrapolating from the most recently available figures. The wealth and pension fund data are not prepared on a consistent basis, but one can make crude comparisons which indicate rough orders of magnitude. The national wealth, estimated at current prices, grew by approximately six per cent per year from 1950 to 1960 (which rate includes some built-in inflation). Thus, pension claims on the national wealth grew from roughly 2.3 per cent to 4.4 per cent in the ten-year period. ${ }^{20}$

As one might suspect, pension funds also have become an important factor with respect to the volume of saving generated annually in the economy, as indicated by table one.

The steady growth in pension saving from $\$$ r.6 billion in 1946 to $\$ 7.9$ billion in 1959 is in itself a noteworthy feature of the structure of saving. The erratic nature of total saving, reflecting the swings of the business cycle, shows up in sharp contrast to pension saving, which is relatively stable in its trend of long-term growth. The percentage of personal saving flowing through pension funds likewise shows a generally increasing trend, provided that the years $x 947$ and 1949 are omitted. In 1947, personal saving virtually disappeared in the rush to make good the accumulated wartime backlog of demand for consumer goods; and in r949 total personal saving dropped sharply in the recession, leaving the then modest amount of pension saving as a large share in the total.

All of the foregoing figures suggest some basic questions. For example, what is likely to be the rate of growth in pension fund assets in the next few decades?

${ }^{10}$ Securities and Exchange Commission, supra note 3.

${ }^{17}$ Unions, non-profit organizations, and multi-employee plans.

${ }^{28}$ All the figures given are from Securities and Exchange Commission, supra note 3.

To Statistical Abstract of the United States 326 ( 1960 ).

${ }^{\infty}$ At the risk of being taken too literally, the author points out that should the indicated prospective rates of growth continue, the various pension funds would own the entire national wealth between 2000 and 2010. Needless to say, there are a number of reasons why such an extreme development is not likely; nevertheless, the impact of such a rapid growth rate as has been experienced by pension funds in the recent past is dramatically illustrated by such a hypothetical projection. 
TABLE I

Net Saving, Pergonal Saving, and Saving Through Pension Funds, I946-r959

(Billions of Dollars)

\begin{tabular}{|c|c|c|c|c|}
\hline \multirow{2}{*}{ Year } & \multirow{2}{*}{$\begin{array}{l}\text { Total Net } \\
\text { Saving }\end{array}$} & \multirow{2}{*}{ Personal Saving } & \multicolumn{2}{|c|}{ Pension Saving } \\
\hline & & & Amount & $\begin{array}{c}\%_{0} \text { of } \\
\text { Personal Saving }\end{array}$ \\
\hline 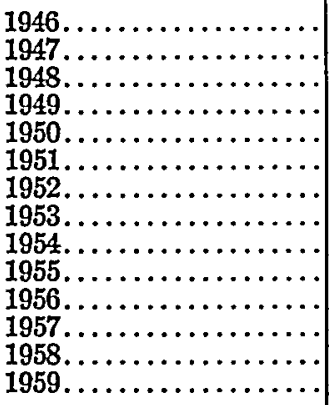 & $\begin{array}{l}19.9 \\
23.9 \\
30.3 \\
15.7 \\
29.4 \\
33.3 \\
24.3 \\
20.5 \\
18.9 \\
30.5 \\
35.8 \\
32.8 \\
19.5 \\
30.9\end{array}$ & $\begin{array}{r}14.2 \\
5.7 \\
12.2 \\
9.8 \\
14.2 \\
19.4 \\
20.7 \\
21.4 \\
20.4 \\
19.3 \\
23.4 \\
25.6 \\
27.1 \\
26.3\end{array}$ & $\begin{array}{l}1.6 \\
2.2 \\
2.5 \\
2.8 \\
3.3 \\
3.8 \\
4.4 \\
4.3 \\
4.5 \\
5.1 \\
5.6 \\
6.1 \\
6.9 \\
7.9\end{array}$ & $\begin{array}{l}11.3 \\
38.6 \\
20.8 \\
28.6 \\
23.2 \\
19.6 \\
21.3 \\
20.0 \\
22.1 \\
26.4 \\
23.9 \\
23.8 \\
25.5 \\
30.0\end{array}$ \\
\hline
\end{tabular}

SOURCz: U. S. Omcz or Busniess Econourcs, Dep'x or Coynesce, U. S. INCOME AND OTTPUT, 1958 (1958) (a supplement to the Survey of Current Business); Surrey of Current Business, May 1961; unpublished data from the Board of Governors of the Federal Reserve System.

Is it likely to (I) continue at the present high levels, (2) increase, or (3) decline? What is the likely course of saving through pension funds as a share of total saving and, in a similar vein, what share in the ownership of the nation's wealth is likely to be held through pension funds?

\section{B. Analysis of Pension Fund Variables}

The volume of accumulated funds in pension plans depends on a number of variables which are examined below. Questions about the future prospects of pension funds may best be answered, then, by evaluating the future prospects for each of the variables, and making some analysis of the impact on required pension funds of likely changes in the variables.

For a single individual, the size of an accumulated pension fund at any given time depends upon his life expectancy, the desired retirement benefit, the length of time he will have worked under the coverage of a pension plan (thus, the time he has available in which to accumulate the required fund), the age at retirement, the rate of return earned on invested funds, the pattern of fund accumulation, and the length of time already covered.

The longer an individual's life expectancy, the greater will have to be, at retirement, the accumulated fund from which benefits are to be paid. Similarly, the larger the desired retirement benefit, the larger will have to be the required fund accumulated at retirement. The earlier the age of retirement (with a given life expectancy) the greater will be the required fund at retirement, and the more rapidly it must be built up over the individual's working life. The lower the 
available interest rate (or rate of return on investments) the greater will be the required fund at retirement needed to support a given level of benefits, and the greater will be the required contributions during the working life.

For the entire economy the same variables, along with certain new factors, determine the size of pension funds in the aggregate. The size and age distribution of the population, the rates of participation in the labor force, and the extent of coverage under pension plans are obviously important factors. Of those covered, eligibility provisions and turnover rates determine the portion which will eventually receive pensions, and the extent of vesting privileges determines the required fund with respect to those who will not. A final factor is the extent to which pension obligations are funded by employers.

As a first approach to an analysis of these variables-and in order to illustrate the manner in which the foregoing variables affect the size of pension funds-let us assume a highly-idealized economy with the following characteristics:

I. The population is fixed at seventy-five million people, one million in each age bracket, 0-74. Each January I there are simultaneously one million births and one million deaths, all of the latter in the group just reaching an age of 75 .

2. Each individual enters the labor force at age $2 \mathrm{r}$ and leaves, via retirement, at age 65. The labor force is thus stabilized at forty-four million.

3. Each worker earns $\$ 5,000$ per year, so that the wage component of the national income is forty-four million $\times \$ 5,000$, or $\$ 220$ billion. Further, each worker belongs to a pension plan which will pay a ro-year retirement pension of $\$ 2,500$ annually, half his working income.

4. No saving is done outside the pension plans, nor has any ever been done in the economy. The pension funds, then, own all of the economy's real capital, either directly or through holdings of securities. As a corollary, all property incomes are received by the pension funds, but are implicitly received by individuals through additions to their pension equities. The latter are household assets, and pension fund liabilities.

5. It is assumed that capital throughout the economy yields three per cent under the given conditions of static equilibrium. In the absence of uncertainty, there is but one rate of return on all property, whether described as dividends, interest, rent, or profit.

6. Government is assumed away, again in order to focus attention on only the variables under consideration.

With the aid of an annuity table, it may be seen that each worker in the economy would make an annual contribution to his pension fund of $\$ 246.67$, which amount, accumulated for 44 years at three per cent would yield the required ten payments of $\$ 2,500$ during the retirement period. Further calculations show that the pension funds would total $\$ 47$ r.6 billion, the summation of accumulated contributions for the workers and retirees in each age bracket. The fund balance is 
stable, since the annual contributions, forty-four million $\mathrm{x} \$ 246.67$ plus interest at three per cent on the fund balance, exactly equal the $\$ 25$ billion paid to retirees.

The value of the economy's production is \$234.I billion, which is the sum of income earned in production. Labor income of $\$ 220$ billion is added to interest and profits amounting to three per cent of the national wealth of $\$ 47 \mathrm{r} .6$ billion (all owned by the pension funds) or \$r4.I billion. Working individuals are saving in an amount just equal to the dissaving of retirees, so that net national saving is zero. As a result, the national wealth does not change; the economy persists in a situation of static equilibrium.

With the aid of such an idealized model of an economy, it is possible to observe the effects of changes in each of the variables in turn, or in all of them simultaneously. Should, for example, life expectancy at retirement rise from to to 20 years, with the working life unchanged at 44 years, interest at three per cent and the same desired benefit of $\$ 2,500$, the required aggregate pension fund would more than double to $\$ 1,035$ billion. Or, should the retirement age be reduced from 65 to 55, with life expectancy unchanged at 75, the required fund would almost double, rising to $\$ I_{5} 5$ billion. If the interest rate should fall to two per cent, with the original assumption of a 44-year working life and a ro-year retired life expectancy unchanged, the required fund would rise by some nine per cent to $\$ 525$ billion. Or, to take an extreme example, should the retirement age fall to 55, life expectancy rise to 85 , and the interest rate, as a result of heavy capital accumulation, fall (only modestly) to two per cent, the required fund would take a four-fold jump to $\$ x, 728$ billion. Needless to say, such an idealized economy will never exist, but it does illustrate vividly the radical changes in pension fund requirements associated with changes in life expectancy, retirement age, and interest rates.

It is possible to formulate, with the aid of mathematics, some equations for pension funds which closely approximate present-day conditions in the United States. While this is not the place for a detailed development of this analysis, some of its results will be summarized briefly. It can be shown that the annual growth rate of pension funds in the aggregate, other things being equal, is roughly approximated by the sum of annual growth rates of the average benefit payable, the per cent of the working population covered, and the extent to which pension liabilities are funded. In other words, should the average benefit, the covered labor force (expressed as a per cent of the labor force) and the funding percentage each be increasing at the rate of three per cent, then pension funds, assuming no changes in any of the other variables, would grow at a rate of approximately nine per cent per year.

The effects of changing longevity, retirement age, vesting provisions, interest rates, and population structure may not be demonstrated so simply, but they are nonetheless of great importance. It can be shown that each year added to life expectancy will increase required pension funds by some four or five per cent, depending on values assigned to other variables. . Earlier retirement, more liberal 
vesting, or lower interest rates likewise increase the size of required funds, though in a manner not reducible to simple expressions. The size and age structure of the labor force, of course, influence the size of pension funds, though again in a rather complex manner which cannot be stated in straight percentage growth rates, as can the effects of some of the variables mentioned earlier.

\section{Conclusion}

In the light of the foregoing discussion, it appears certain that pension funds are likely to continue their rapid growth. Average benefits and coverage of the labor force have grown steadily in recent years; the life span continues to lengthen; and there is apparently a tendency toward more liberal vesting provisions. The only factors which could possibly operate to reduce pension funds at the present time are higher interest rates or a reduction in the extent to which pension liabilities are funded. It seems unlikely that interest rates higher than those experienced in 1959 and 1960 will appear. With respect to funding practices, we simply do not have sufficient information. The author is inclined to doubt, however, that any significant reduction will occur.

Pension funds are thus not likely to stop growing unless there is a radical reversal of trends in the variables examined above. As to probable rates of growth over the next few decades, there is room for a great variety of opinion. Vito Natrella, Chief Statistician of the Securities and Exchange Commission, estimated in 1956 that noninsured private funds would amount to $\$ 29.2$ billion by 1960 , a figure very close to the $\$ 28.7$ billion (at book value) actually realized. The same study projected a 1965 total of $\$ 5$ r.7 billion. ${ }^{21}$ Professor Harbrecht, using less refined methods, made an even closer $x 960$ estimate of $\$ 28.6$ billion, ${ }^{22}$ though he had the benefit of one more year's figures.

There has been some speculation among researchers in the field as to when pension fund growth will level off. It is true, of course, that once the era of rapid expansion of coverage is over, funds will grow more slowly. However, even given full coverage, there will be some growth resulting from increases of the population and of the labor force. Added to this, we might expect a pattern of rising benefits to produce an annual rate of increase in required funds in the order of one to three per cent, and a continued lengthening of life expectancy at retirement to add another one half per cent or so. Funding and vesting practices leave a great deal of leeway, but the conclusion appears to be warranted that the rate of pension fund growth will not ever fall below four or five per cent, and will remain well above that figure for at least another five to ten years as coverage continues to widen.

Under such assumptions, pension funds could grow from the present $\$ 83.3$ bil-

\footnotetext{
${ }^{21}$ Natrella, Implications of Pension Fund Accumulations, in American Statistical Ass'N., Pro. CEEDINGS I4 (1957).

${ }^{2}$ HARBRECHT, op. cit. supra note 14 , at $24 x$.
} 
lion to $\$ 150$ or $\$ 160$ billion by 1965 , and could reach from $\$ 250$ to $\$ 350$ billion by 1975. Unless the penchant for common stocks exhibited by fund managers alters somewhat, we are likely to experience still higher stock prices (and lower yields), along with an increased volume of equity financing by corporations. On the other hand, any substantial shift from equities to debt instruments could lead to rapid and sizable shifts in the structure of yields. At any rate, the economic and legal problems associated with pension funds are likely to be with us for a long time; past experience suggests that we shall, in due time, develop the necessary political and legal institutions to deal with them. 